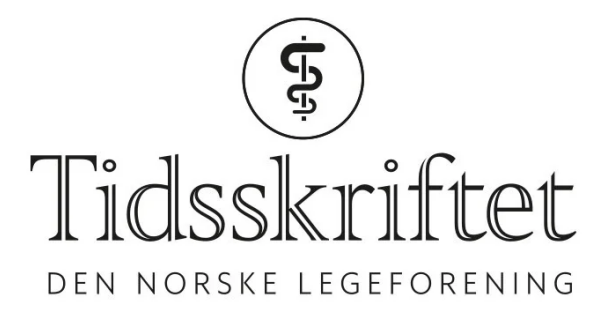

\title{
Et antiviralt legemiddel mot covid-19?
}

FRA ANDRE TIDSSKRIFTER

HAAKON B. BENESTAD

Universitetet i Oslo

Klofazimin, som kan brukes mot lepra, har god virkning på cellulært opptak og reproduksjon av SARS-CoV-2-virus i flere testsystemer, spesielt sammen med remdesivir.

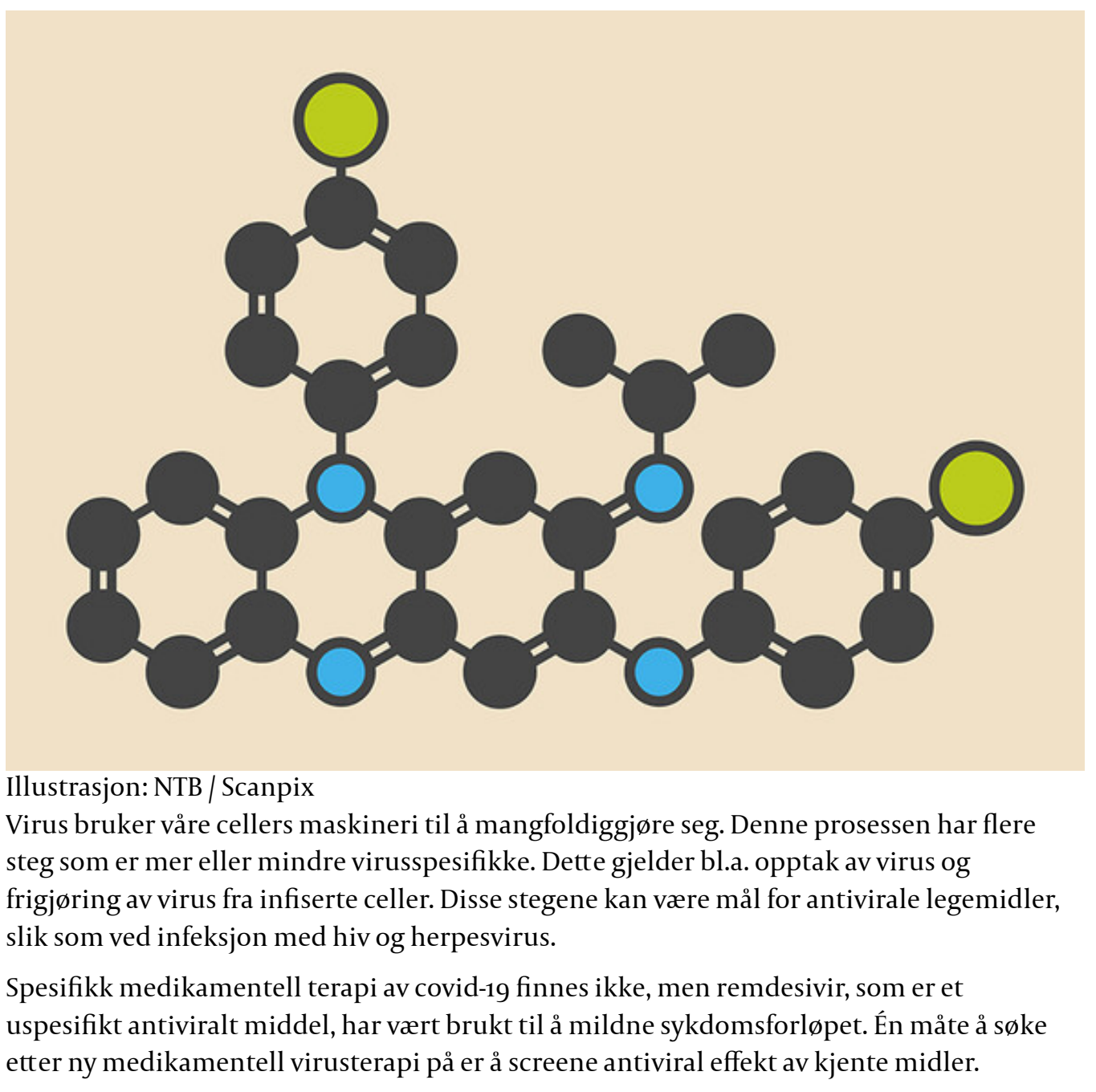


Klofazimin, som brukes mot lepra og tuberkulose, er et slikt legemiddel. Det gis per os, er relativt billig og har en gunstig bivirkningsprofil.

I en ny studie med humane primærkulturer og cellelinjekulturer, hemmet klofazimin reproduksjonen av flere koronavirustyper som SARS-CoV-2 og MERS-CoV (1). Medikamentet hemmet både virusopptaket i målceller og et enzym som trengs for virusformeringen $i$ målcellene. I en hamstermodell hadde medikamentet en profylaktisk effekt. Det hemmet virusinfisering etter tre dagers bruk før infisering. Effekten var også terapeutisk: Virusopptaket i lungeceller ble hemmet, virusutskillelsen i feces ble redusert og inflammasjonen, målt med inflammasjonsmarkøren IL-6, ble dempet. Kombinasjoner av klofazimin og remdesivir hadde en potensert synergistisk virkning.

- Å teste ut ny bruk av kjente medikamenter er en mulig vei for raskt å finne ny behandling mot covid-19 og andre sykdommer, sier Finn Olav Levy, som er professor ved Avdeling for farmakologi ved Universitetet i Oslo og Oslo universitetssykehus. Disse studiene viser at klofazimin har antivirale effekter sammenlignbare med effektene av remdesivir, som ikke har klinisk effekt, og som WHO nå fraråder å bruke.

- Mest interessant er kanskje funnet av synergistisk effekt ved kombinasjon av klofazimin og remdesivir, sier Levy, og at klofazimin har både antivirale og antiinflammatoriske effekter. Uansett må eventuelle effekter mot covid-19 avklares i kliniske studier, og kun én liten studie om klofazimin mot covid-19 er registrert i clinicaltrials.gov.

- Dette kan skyldes at legemidlet ikke anses å være interessant nok, at funnet av dets antivirale effekter er helt nytt, eller at det er lite penger å tjene på en ny indikasjon for et billig medikament, sier Levy.

\section{LITTERATUR}

1. Yuan S, Yin X, Meng X et al. Clofazimine broadly inhibits coronaviruses including SARS-CoV-2. Nature 2021; 593: 418-23. [PubMed][CrossRef]

Publisert: 3. september 2021. Tidsskr Nor Legeforen. DOI:10.4045/tidsskr.21.0500

(C) Tidsskrift for Den norske legeforening 2023. Lastet ned fra tidsskriftet.no 26. april 2023. 